DOI: $10.17516 / 1997-1370-0582$

УДК 330.3

\title{
Cultural Heterogeneity and Economic Development in Russia
}

\author{
Anna N. Bufetova*, Alina A. Khrzhanovskaya \\ and Evgeniya A. Kolomak \\ Institute of Economics and Industrial Engineering of the SB RAS \\ Novosibirsk, Russian Federation \\ Novosibirsk National Research State University \\ Novosibirsk, Russian Federation
}

Received 11.11.2019, received in revised form 10.03.2020, accepted 10.04.2020

\begin{abstract}
The paper studies change in the national and religious structure of the population and assesses the impact of cultural heterogeneity on the economic development of Russian regions. Sources of information on the national structure of the population are 2002 and 2010 censuses. The analysis of heterogeneity in the religious structure is carried out for 2012 and 2015 and sources of the data are Atlas of Religions and Nationalities of Russia and the Federal Agency for Nationality Affairs. Fractionalisation and polarisation indices are used to assess the level of cultural heterogeneity. The study of these characteristics showed that despite the intensification of migration processes in contemporary Russia, there were no major changes in the cultural structure of the population of the regions. At the same time, there is a wide variety of national and religious structures in the regions. The impact of cultural heterogeneity on economic development is estimated using regression analysis. The panel regression of gross regional product on labor, capital, controlling variables and indices of cultural heterogeneity is estimated. The results have shown: 1) the positive impact of ethnic and cultural fractionalisation on economic development; 2) the absence of a statistically significant relationship between the level of national polarisation and development; 3 ) the negative impact of religious polarisation on regional productivity. The results suggest that it is necessary to consider cultural heterogeneity of the society and the possibility of contradictions due to the cultural differences in the regional policy and in the decisions on the public finance.
\end{abstract}

Keywords: cultural heterogeneity, Russian regions, nationality, religion, empirical analysis, fractionalisation, polarisation, regression.

The authors are grateful to the Russian Foundation for Basic Research for the financial support of the research (Grant No. 19-310-90010).

Research area: economics.

\footnotetext{
(C) Siberian Federal University. All rights reserved

* Corresponding author E-mail address: bufetova@gmail.com, AlinKhrzh57@mail.ru, ekolomak@academ.org

ORCID: 0000-0003-4253-7079 (Bufetova); 0000-0003-2374-0098 (Khrzhanovskaya); 0000-0002-2230-852X (Kolomak)
} 
Citation: Bufetova, A.N., Khrzhanovskaya, A.A., Kolomak, E.A. (2020). Cultural heterogeneity and economic development in Russia. J. Sib. Fed. Univ. Humanit. Soc. Sci., 13(4), 453-463. DOI: $10.17516 / 1997-1370-0582$.

\section{Introduction}

Economic theory recognises that informal institutions and culture, in particular, can have a significant impact on economic performance. Culture is involved in shaping preferences, restrictions, attitudes to other institutions, and behaviour patterns. Culture determines the effectiveness of formal rules, influences the choice of political and organisational structure, the success of reforms and, ultimately, the level of development of a society. Most countries and regions have a heterogeneous population in terms of cultural characteristics. Cultural diversity creates both positive and negative effects. The former ones are explained by the combination of advantages of different cultures, by their complementarity in production, by a variety of skills, experience and ideas. The negative consequences are associated with possible costs due to mismatch of values, coordination problems because of different behaviour, potential political and social conflicts, barriers and disagreements on policy priorities. Active migration processes and the growth of labor mobility on a global scale bring changes in the ethnic, religious and national structures of the population, which raises questions about the socio-economic consequences of these phenomena and effective political reactions.

Cultural diversity is one of the aspects of the problem of social heterogeneity, and several theoretical studies (Esteban, Ray, 1994; Esteban, Ray, 1999; Nehring, Puppe, 2002) are devoted to this issue. It is proposed to separate two characteristics of the diversity: fractionalisation and polarisation, which are associated with different levels of risk of negative consequences for a society.

The study of the effects of ethnic heterogeneity was initiated by Perotti's work (Perotti, 1996), which shows that political instability has a negative impact on growth through mechanisms for distributing economic benefits, but ethnic fractionalisation does not have a statistically significant impact on it. The paper of Alesina and Perotti (Alesina, Perotti, 1996) analysed the channel of influence through investment, and the authors came to the similar conclusion.

A special contribution to the debate was made by the article of Easterly and Levin (Easterly, Levine, 1997), which analysed the effects on long-term economic growth in Africa in 1960-1990 and found a statistically significant negative impact of ethnic diversity on development. Channels of the influence were public goods, financial repression, and policies in favour of the elites. Polarisation of different ethnic groups leads to rent-oriented behaviour and disagreements regarding the distribution of public goods (Horowitz, 1985).

In (Sokoloff, Engerman, 2000), the authors analysed migration to America, comparing the development of different American countries, and concluded that in a number of countries, elite groups created institutions in their favour, infringing on the rest of the population, which negatively affected economic development. In this case, the behaviour of influential elites was important, they excluded a part of the population from the distribution of economic benefits. This idea was developed in (Keefer, Knack, 2002), which shows a statistically significant negative impact of polarisation on economic growth due to increased risks to property rights.

Exploring the effects of ethnic diversity on economic growth, Putnam (Putnam, 1995), as well as Alesina and La Ferrera (Alesina, La Ferrara, 2000; Alesina, La Ferrara, 2001) emphasise the role of trust, showing that members of different racial groups are less likely to participate in common social activities and trust their neighbours less. Consent for the redistribution of goods is worse in racially diverse communities, this case is also applied to the provision of public goods (Alesina, Baqir, Easterly, 1999). In (Esteban, Mayoral, Ray, 2012) authors investigate conflicts related to the distribution of public goods and conclude that the 
polarisation index positively correlates with the occurrence of conflicts over public goods.

In (Collier, 2001; Easterly, 2001; Papyrakis, Mo, 2014) it is shown that the negative impact of ethnic heterogeneity is less if there are democratic institutions that act as mediators in national conflicts. The studies by Bluedorn (Bluedorn, 2001) and later by Alesina and coauthors (Alesina et al., 2003) show that the negative impact of the diversity on economic growth is stronger in less democratic countries. With a high level of ethnic diversity, weak institutions have a more adverse effect on growth and policy. In countries with relatively developed institutions, ethnic diversity does not constrain growth or impair economic policies, the democratic institutions reduce the risk of conflict and genocide. Fearon and Laitin (Fearon, Laitin, 2003) add that ethnic diversity is not a sufficient explanation for the beginning of civil conflicts and a measure of polarisation should be used.

The difference in the impact of ethnic diversity on economic growth depends on a study object. Thus, at the country level, the relationship between ethnic diversity and economic growth is negative, but at the regional and urban levels, the authors found that there is a positive relationship between them. Alesina and La Ferrara (Alesina, La Ferrara, 2005) compare effects of the ethnic diversity at the regional level in developed countries; comparing the American states, they found out the negative impact of ethnic diversity only in the poor states.

Most studies for the city level have found that heterogeneity has a positive effect on such indicators as wages and productivity. In (Ottaviano, Peri, 2006) the authors found that on average, cultural diversity has a net positive effect on American productivity. In (Sparber, 2010) a positive relationship was found between racial heterogeneity and wages in the United States. Lee (Lee, 2011) used employee career data for 53 English cities between 1981 and 2001 and showed that cities with more diverse populations experienced faster economic growth.

The third level of the analysis presented in the literature is companies. In (Lee, 2015) the author compared the effect of diversity for firms and cities and found a positive effect of diversity in companies on innovation. Assuming that immigrants bring different ideas and abilities, and are important factors in the technological progress, Alesina, Harnos and Rappoport (Alesina, Harnoss, Rapoport, 2013) analysed the relationship between the diversity of immigrants and the level of economic development and concluded that it had a positive impact. Many papers support the suggestion that diversity leads to increased productivity when skills are complementary (Lazear, 1999; Hamilton, Nickerson, Owan, 2003; Parotta, Dario, Mariola, 2010).

The conclusion about the negative impact of diversity on economic development or its absence is often made when a high level of aggregation is used, but a positive relationship is revealed in the analysis at the level of cities and enterprises. A more detailed approach is increasingly used in the study of ethnicity and institutions (Michalopoulos, Papaioannou, 2013; Michalopoulos, Papaioannou, 2014), ethnicity and inequality (Alesina, Michalopoulos, Papaioannou, 2015).

There are few papers that study the relationship between ethnic and cultural diversity and economic development in contemporary Russia (Limonov, Nesena, 2015; Nesena, Razumovsky, 2016; Bufetova, Kolomak, 2017; Bufetova, Kolomak, Khrzhanovskya, 2018). Empirical analysis did not reveal stable relationships and patterns. This paper attempts to present a more detailed study by separating the effects of polarisation and fractionalisation of both national and religious heterogeneity.

\section{Theoretical framework}

The paper is based on the conclusions of the theories of economic growth and institutional economics, which consider culture as an important informal institution that forms preferences, restrictions, and models of interaction and behaviour of people.

The results of empirical studies on the socio-economic and political consequences of the cultural diversity are ambiguous and depend on the objects studied and on the estimated impact directions. This can be explained by the fact that the influence of the cultural heterogeneity 
on economic development is not direct, it is mediated by the system of formal institutions, by the structured social relations, and by the traditions of interpersonal relations. The channels of influence of the cultural heterogeneity on the results of economic activity are trust, transfer of experience, preferences for public goods and public choice procedures. In this regard, the degree and direction of influence of the cultural heterogeneity on the socio-economic processes are determined by the technological progress, diversity of production, costs of coordinating the preference for public goods, the role of powerful elites representing ethnic or religious groups in government policy, restrictions on rent-seeking elites, the development of democratic institutions, social cohesion and capacity for collective action.

Empirical studies on the impact of cultural diversity on economic development are based on models of economic growth. The specification of the model, along with the fundamental factors of production, which are labor and capital, includes characteristics of cultural diversity, while controlling the features of the institutional environment that can directly or indirectly affect the results of the interaction.

Cultural heterogeneity is measured using several indicators, including the fractionalisation index and polarisation index. The potential positive effects of the heterogeneous structure reflect rather the first indicator - the fractionalisation index. And the probability of social conflicts, which may be based on cultural heterogeneity, is estimated using the polarisation index. The risk of social tensions depends not on the number of ethnic or religious groups as on the distribution of the population among them, and not so much on the level of heterogeneity, but on its structure. Inequality does not always cause open conflict, social protest is a collective action and requires concentration of interests and political forces, i.e. polarisation of the society is necessary. We can talk about the polarisation if the following conditions are met: firstly, there is a high degree of homogeneity within each group and, secondly, there is a high degree of heterogeneity between groups. Polarisation involves analysis of distribution, while fractionalisation does not allow us to identify the details of the heterogeneity structure, to determine the presence of dominant groups.

The analysis of the impact of the cultural heterogeneity in Russian regions on the economic development uses the fact that the country is a multinational state with a large ethnic and religious diversity and, at the same time, there are large differences in the level and dynamics of regional development. National, ethnic, and religious groups are distributed very unevenly across the territory of Russia: from the concentration in some regions to a small representation in others. However, the macroeconomic and institutional environment within a country is more uniform compared to the level of differences between countries and estimates for regions remove the problem of extremely different conditions and specificity of different countries.

\section{Statement of the problem}

The problem of national and ethnic conflicts has become one of the most discussed topics in the media in the recent years. Increased migration due to economic problems, rising unemployment, crises and wars are changing the population structure. Rapid changes in the national structure and the growing heterogeneity of the population, where different ethnic or religious groups have different interests and norms of behaviour, cause tension in the society.

It is known that informal rules grow out of traditions and culture, and diversity in the institutional environment is often determined by national characteristics, which also influence the nature of development. The factor of national heterogeneity and ethnic diversity has impact on economic dynamics, and its direction remains unclear. A number of papers prove the positive impact of ethnic heterogeneity of the population on economic growth and labour productivity. The explanation is that diversity makes it possible to optimally combine the advantages of different cultures and traditional skills. The positive effect of national diversity is mainly characteristic of countries with a high level of development and political stability. But many studies also reveal a negative relationship between ethnic and religious heterogeneity of 
the population with indicators of development and economic efficiency. A whole range of arguments are given as reasons for this dependence. First, in ethnically heterogeneous societies, there is a greater likelihood of conflicts between population groups and related political instability, including armed clashes and civil wars, which negatively affects investment activity and, as a result, the rate of economic growth. Second, in ethnically heterogeneous societies, it is more difficult to reach consensus on the distribution of public goods, so the efficiency of providing budget services is lower. Third, because of the mismatch of interests, groups seek channels of influence on political decisions, wasting development resources in an unproductive way. As a result, in heterogeneous societies the level of corruption is higher, and the participation of citizens in public life is lower due to distrust to the authorities. Finally, ethnic heterogeneity can slow down the diffusion of ideas and technological innovations as a result of cross-cultural and language barriers.

Despite the fact that the Russian Federation is a multi-ethnic state with a great cultural diversity, and as a result of active migration and immigration in recent years, it is possible to assume noticeable changes in the national and religious composition of the population. This work complements the study of the processes of changing the national structure of the population, conducting a detailed analysis of the characteristics of ethnic and religious heterogeneity for the post-Soviet Russia using a set of empirical indicators and techniques.

Cultural heterogeneity can be the cause of both positive and negative socio-economic phenomena. The theoretical and empirical results give grounds to separate these effects and put forward the following hypotheses.

1. Cultural diversity has a positive impact on economic development.

2. The polarised cultural structure negatively affects the socio-economic results of development.

\section{Methods and data}

Quantitative estimates of the national heterogeneity of the population are carried out using the fractionalisation index, which shows the probability that two randomly selected people belong to different cultural groups, and is calculated as follows:

$$
F R A C=1-\sum_{i=1}^{N}\left(s_{i}\right)^{2}
$$

where si is the share of the population of the i-th cultural group in the total population, $\mathrm{N}$ is the number of such groups. The index takes

values from 0 to $1-1 / N$. The minimum value

corresponds to a situation when the society is completely homogeneous and unites the population of one culture. The higher the index the higher the heterogeneity of the population. Theoretically, the index can reach a maximum value of 1 when the number of groups tends to infinity, and all people belong to different groups. It means that the index depends on the number of cultural groups and increases with the number. Another property of the fractionalisation index that needs to be considered is that it depends on the distribution of the population by group, giving greater weight to large groups of the population. As a result, if the share of the dominant cultural group decreases, the fractionalisation index will decrease. However, the study of dynamics using this indicator with unchanged classifications is quite correct.

Cultural heterogeneity can be the source of disagreements in society. From this point of view, the diversity measure should reflect the possibility of conflicts. However, the threat of social tension is not so much related to the number of cultural groups, as to the nature of the distribution of the population between them, that is, not to the level of heterogeneity, but to its structure. Inequality is not always a source of conflict; social protest is a collective action and is associated with the polarisation of society. We can talk about the polarisation of society if the following conditions are met: firstly, there is a high degree of homogeneity within each group and, secondly, there is a high degree of heterogeneity between the groups. Thus, the polarisation involves the analysis of distribution features. And the fractionalisation index does not allow to identify the features of the heterogeneity structure, to determine whether a society is bipolar, multipolar or bal- 
anced, to identify the presence of a dominant majority or a dominant minority. Esteban and Rey (Esteban, Ray, 1994) proposed the polarisation index, they formulated the theoretical basis for the polarisation evaluating and a system of axioms that must satisfy the measure of polarisation. The constructed polarisation index that satisfies these axioms is calculated as follows:

$$
\begin{aligned}
& P(s, y, k, \alpha)= \\
& =k \sum_{i=1}^{N} \sum_{i \neq j} s_{i}^{1+\alpha} s_{j}\left|y_{i}-y_{j}\right|,
\end{aligned}
$$

where $s_{i}$ is a share of the $i$-th group in the total population, $\left|y_{i}-y_{j}\right|$ is a measure of the difference (distance) between the two groups $i$ and $j$, $\alpha$ and $k$ are parameters.

This index was used to assess the degree of polarisation of the population by wealth and income, but in analysing the polarisation of the population by cultural characteristics, we face the problem that it is necessary to set a quantitative assessment of the level of differences between cultural groups. One of the attempts to solve this problem is presented in the paper (Montalvo, Reynal-Querol, 2002), where the polarisation index is a measure of the difference between the actual distribution of the population by ethnic groups and the bimodal distribution:

$$
Q=1-\sum_{i=1}^{N}\left(\frac{0.5-s_{i}}{0.5}\right)^{2} s_{i} .
$$

In the formula, the deviation of the share of each group from its maximum value at the extreme degree of polarisation (0.5) is weighted by the value of this share. The proposed index reaches a maximum when the society splits into two groups of equal size and decreases when its structure deviates from this pattern. Montalvo and Raynal-Querol (Montalvo, Reynal-Querol, 2002) showed that the polarisation index $Q$ belongs to the class of polarisation measures proposed by Esteban and Rey (Esteban, Rey, 1994). Due to the complexity of determining the degree of difference between cultural groups, the authors assumed that the differences between any groups are equal.

The fundamental difference between the fractionalisation and polarisation indices is that an increase in the number of groups increas- es the fractionalisation index (the diversity of the population is higher) but reduces the polarisation index (it is maximum if there are two large groups). Therefore, the fractionalisation and polarisation indices characterise different aspects of population heterogeneity and are used to study different influence on economic development.

The analysis of the impact of cultural heterogeneity on development indicators is carried out using economic growth models. Empirical studies use regression of output on labour, capital, a system of controlling variables, and cultural heterogeneity indices. The implementation of this approach gives the specification of the econometric model as follows:

$$
\begin{aligned}
& \ln Y_{i t}=\beta_{0}+\beta_{1} \ln C_{i t}+\beta_{2} \ln L_{i t}+ \\
& +N D_{i t}+D P_{i t}+\mu_{i}+\lambda_{t}+\varepsilon_{i t} .
\end{aligned}
$$

Where

$Y_{i t}$ - gross regional product in region i in year t; $C_{i t}$ - fixed capital in region $\mathrm{i}$ in year t; $L_{i t}-$ employment in region $\mathrm{i}$ in year $\mathrm{t}$; $N D_{i t}$ - cultural diversity index in region $\mathrm{i}$ in year $\mathrm{t}$;

$D P_{i t}-$ cultural polarisation index in region $\mathrm{i}$ in year $\mathrm{t}$;

$\mu_{i}$ - regional effect;

$\lambda_{t}-$ time effect.

Important determinants of cultural differences are nationality and religion. The national structure of the Russian population is presented in 2002 and 2010 censuses. Information about the confessional structure of the population is available for 2012 in the Atlas of Religions and Nationalities of Russia, data for 2015 were prepared by the Federal Agency for Nationality Affairs. The confessional structure of the population of the Russian Federation, despite the dominance of the Orthodox religion, is quite diverse. Data for 2012 gives a more detailed structure of religions. Therefore, to ensure comparability, the 2015 grouping was taken as a basis, including the following religions: Orthodox, Islam, Buddhism, atheism, own faith, Protestantism, Christianity (but not Orthodox, Catholic, or Protestant), Judaism, Eastern religions and spiritual practices, Pentecostalism, paganism, old believers, Catholicism, etc. 


\section{Discussion}

There were no major changes in the national diversity of the population in the Russian regions during the period under review (Table 1), while significant changes were observed in the heterogeneity of the religious structure (Table 2). The religious composition is more heterogeneous than the national one. However, both the ethnic and religious structures tended to increase homogeneity; the average values and median level of the fractionalisation indices declined. But, at the same time, interregional differences increased; the coefficients of variation and standard deviations were getting bigger.

The index of national polarisation in the regions varies from 0.1 to 0.9 (Table 3 ), and the religious polarisation from 0.2 to 0.9 (Table 4), which indicates a high cultural polarisation in certain regions. The average characteristics of the national polarisation for Russia can be attributed to moderate, while for the religious polarisation the average characteristics are quite high. But the average level of cultural polarisation in the country is reducing.

The obtained estimates bring to the conclusion that there is a wide variety of cultur-

Table 1. The index of the national fractionalisation in Russian regions

\begin{tabular}{llll}
\hline & 2002 & 2010 & $\Delta 2002-2010$ \\
\hline Minimum & 0.059 & 0.054 & -0.005 \\
\hline Maximum & 0.838 & 0.835 & -0.003 \\
\hline Average & 0.295 & 0.277 & -0.018 \\
\hline Median & 0.230 & 0.188 & -0.042 \\
\hline Standard deviation & 0.199 & 0.200 & 0.001 \\
\hline Variation coefficient & 0.675 & 0.724 & 0.049 \\
\hline
\end{tabular}

Table 2. The index of the religious fractionalisation in Russian regions

\begin{tabular}{llll}
\hline & 2012 & 2015 & $\Delta 2012-2015$ \\
\hline Minimum & 0,370 & 0,145 & $-0,225$ \\
\hline Maximum & 0,816 & 0,784 & $-0,032$ \\
\hline Average & 0,697 & 0,498 & $-0,199$ \\
\hline Median & 0,714 & 0,507 & $-0,208$ \\
\hline Standard deviation & 0,088 & 0,130 & 0,042 \\
\hline Variation coefficient & 0,127 & 0,261 & 0,135 \\
\hline
\end{tabular}

Table 3. The index of the national polarisation in Russian regions

\begin{tabular}{llcc}
\hline & 2002 & 2010 & $\Delta 2002-2010$ \\
\hline Minimum & 0.113 & 0.104 & -0.009 \\
\hline Maximum & 0.912 & 0.926 & 0.014 \\
\hline Average & 0.444 & 0.420 & -0.024 \\
\hline Median & 0.390 & 0.336 & -0.054 \\
\hline Standard deviation & 0.241 & 0.248 & 0.007 \\
\hline Variation coefficient & 0.543 & 0.592 & 0.049 \\
\hline
\end{tabular}


Table 4. The index of the religious polarisation in Russian regions

\begin{tabular}{lccc}
\hline & 2012 & 2015 & $\Delta 2012-2015$ \\
\hline Minimum & 0,560 & 0,274 & $-0,286$ \\
\hline Maximum & 0,859 & 0,915 & 0,056 \\
\hline Average & 0,709 & 0,693 & $-0,016$ \\
\hline Median & 0,708 & 0,714 & 0,006 \\
\hline Standard deviation & 0,059 & 0,115 & 0,056 \\
\hline Variation coefficient & 0,083 & 0,165 & 0,082 \\
\hline
\end{tabular}

al structures in the regions of Russia, which allows us to study the relationship between cultural heterogeneity and indicators of social and economic development. Since information about the national and religious structure of the population is presented for different years, the regression estimates for these cultural characteristics were run separately.

Considering that inflation processes had different activity in the spatial dimension and over time, the gross regional product (GRP) was recalculated based on the indices of the physical volume of GRP. We have panel regression and should choose between fixed and random effects models. The Hausman test did not reveal significant differences in the estimates of models with fixed and random regional and time effects, so GLS estimates were used, which are more efficient. The estimates of the regressions (4) are presented in Table 5.

Like many empirical studies for a regional level, our regression estimates confirmed the hypothesis of a positive impact of cultural di- versity on economic development in Russian regions. The coefficients for the national and religious fractionalisation indices are positive and statistically significant. At the same time, the hypothesis about the negative impact of cultural polarisation was confirmed only for the religious component. The coefficients for national and religious polarisation indices have a negative sign, but the national polarisation index is statistically insignificant.

\section{Conclusion}

Our estimates have shown that despite the growth of the internal and international mobility of the population, there were no significant changes in the diversity of the cultural structure in Russia. This result does not correspond to the popular opinion that the country experienced growing heterogeneity of national and religious structures. This assumption is based on the idea that active migration in the post-Soviet period should result in a more diverse cultural and ethnic composition. However, the obtained

Table 5. Regression estimates for cultural heterogeneity

\begin{tabular}{|l|c|c|c|c|}
\hline \multirow{2}{*}{\multicolumn{1}{|c|}{ Variable }} & \multicolumn{2}{c|}{ Regression 1 } & \multicolumn{2}{c|}{ Regression 2 } \\
\cline { 2 - 5 } & coefficient & P-value & coefficient & P-value \\
\hline Fixed capital & 0.386 & 0.000 & 0,3206 & 0,000 \\
\hline Employment & 0.661 & 0.000 & 0,6649 & 0,000 \\
\hline National fractionalisation & 0.381 & 0.078 & & \\
\hline National polarisation & -0.295 & 0.251 & & 0,000 \\
\hline Religious fractionalisation & & & $-0,2131$ & 0,001 \\
\hline Religious polarisation & & 164 & 164 & 164 \\
\hline Number of observations & \multicolumn{2}{|c|}{0.89} & & 0.90 \\
\hline R2 & \multicolumn{2}{|c|}{} \\
\hline
\end{tabular}


quantitative estimates did not confirm this hypothesis. This can be explained by the fact that the cultural structure of migrants is not very diverse, so demographic mechanical processes are not accompanied by an increase in cultural heterogeneity of the whole population.

The intercultural relations are not sources of acute conflicts and their institutional representation, formed over decades, have not experienced significant pressure and have not required significant changes. Assessments have shown that both national and religious diversity are positively correlated with the regional development. Due to the relative stability of the formal and informal institutional structures, the national diversity has shown positive effects, while the negative phenomena that are usually associated with the polarisation have not received a basis for development in inter-ethnic relations. However, religious polarisation has a negative impact on regional productivity. This phenomenon can be explained, firstly, by the fact that Russia has developed traditions and experience in managing inter-ethnic relations over the centuries, while the inter-religious interactions in our country do not have such a long history, and mechanisms for their coordination are only in the process of development. In addition, confessional differences in behaviour patterns and assessments of situations are more significant, and, accordingly, can create more serious contradictions in society.

Summarising, we can say that cultural characteristics can be both a source and a barrier for the development in Russia. This informal institution should be taken into account into the political decision-making and in the public finances managing. Given the large inter-regional differences in the national and religious structures of the population, a replication of management practices has very limited opportunities; regions must rely on their own experience and develop original models of governance.

\section{References}

Alesina, A., Baqir, R., Easterly, W. (1999). Public Goods and Ethnic Divisions. In Quarterly Journal of Economics, 114 (4), 1243-284.

Alesina, A., Devleeschauwer, A., Easterly, W., Kurlat, S., Wacziarg, R. (2003). Fractionalization. In NBER Working Papers 9411.

Alesina, A., Harnoss, J., Rapoport, H. (2013). Birthplace Diversity and Economic Prosperity. In NBER Working Paper.

Alesina, A., La Ferrara, E. (2000). Participation in Heterogeneous Communities. In Quarterly Journal of Economics, 115 (3), 847904

Alesina, A., La Ferrara, E. (2001). Who Trusts Others? In Journal of Public Economics, 85 (2), $207-234$.

Alesina, A., La Ferrara E. (2005). Ethnic Diversity and Economic Performance. In Journal of Economic Literature, 43 (3), 762-800.

Alesina, A., Michalopoulos, S., Papaioannou, E. (2015). Ethnic Inequality. In Journal of Political Economy, 124 (2), 428-488.

Alesina, A., Perotti, R. (1996). Income Distribution, Political Instability and Investment. In European Economic Review, 40 (6), 1203-1228.

Bluedorn, J. (2001). Can Democracy Help? Growth and Ethnic Divisions. In Economics Letters, 70 (1), 121-126.

Bufetova, A., Kolomak, E. (2017). Natsional'naia neodnorodnost' v regionakh Rossii [National Diversity in Russian Regions]. In EKO [ECO], 4, 110-123.

Bufetova, A., Kolomak, E., Khrzhanovskaya, A. (2018). Natsional'noe i religioznoe raznoobrazie regionov Sibiri [National and Religious Diversity of Siberian Regions]. In EKO [ECO], 5, 28-44.

Collier, P. (2001). Ethnic Diversity: An Economic Analysis of Its Implications. In Economic Policy, $32,129-166$.

Easterly, W. (2001). The Elusive Quest for Growth: Economists' Adventures and Misadventures in the Tropics. Cambridge MA, MIT Press, 342 p. 
Easterly, B., Levine, R. (1997). Africa's Growth Tragedy: Policies and Ethnic Divisions. In Quarterly Journal of Economics, 112 (4), 1203-1250.

Esteban, J., Mayoral, L., Ray, D. (2012). Ethnicity and Conflict: An Empirical Study. In American Economic Review, 102 (4), 1310-1342.

Esteban, J., Ray, D. (1994). On the Measurement of Polarization. In Econometrica, 62 (4), 819-851.

Esteban, J., Ray, D. (1999). Conflict and Distribution. In Journal of Economic Theory, 87 (2), 379-415.

Fearon, J., Laitin, D. (2003). Ethnicity, Insurgency, and Civil War. In American Political Science Review, 97 (1), 75-90.

Hamilton, B., Nickerson, J., Owan, H. (2003). Team Incentives and Worker Heterogeneity: An Empirical Analysis of the Impact of Teams on Productivity and Participation. In Journal of Political Economy, 111 (3), 465-497.

Horowitz, D. (1985). Ethnic Groups in Conflict: Theories, Patterns, Policies. Berkeley, CA, University of California Press, 707 p.

Keefer, P., Knack, S. (2002). Polarization, Politics, and Property Rights: Links Between Inequality and Growth. In Public Choice, 111 (1-2), 127-154.

Lazear, E.P. (1999). Globalization and the Market for Teammates. In Economic Journal, 109 (454), $15-40$.

Lee, N. (2011). Ethnic Diversity and Employment Growth in English Cities. In Urban Studies, 48 (2), 407-425.

Lee, N. (2015). Migrants and Ethnic Diversity, Cities and Innovation: Firm Effect or City Effects? In Journal of Economic Geography, 15 (4), 769-796.

Limonov, L., Nesena, M. (2015). Osobennosti etno-kul'turnogo raznoobraziia rossiiskikh regionov [Features of the Ethno-Cultural Diversity of Russian Regions]. In Region: ekonomika i sotsiologiia [Region: Economy and Sociology], 3, 146-170.

Michalopoulos, S., Papaioannou, E. (2013). Pre-Colonial Ethnic Institutions and Contemporary African Development. In Econometrica, 81 (1), 113-152.

Michalopoulos, S., Papaioannou, E. (2014). National Institutions and Subnational Development in Africa. In Quarterly Journal of Economics, 129 (1), 151-213.

Montalvo, J., Reynal-Querol, M. (2002). Why Ethnic Fractionalization? Polarization, Ethnic Conflict and Growth. In UPF Working Paper No. 660.

Nehring, K., Puppe, C. (2002). A Theory of Diversity. In Econometrica, 70 (3), 1155-1198.

Nesena, M., Razumovsky, V. (2016). Vzaimosviaz pokazatelei etnicheskogo raznoobraziia i proizvoditel'nosti rossiiskikh regionov [The Relationship Between the Indicators of Ethnic Diversity and Productivity of Russian Regions]. In Region: ekonomika i sotsiologiya [Region: Economy and Sociology], 2, 81-101.

Ottaviano, G., Peri, G. (2006). The Economic Value of Cultural Diversity: Evidence from U.S. Cities. In Journal of Economic Geography, 6 (1), 9-44.

Papyrakis, E., Mo, P. (2014). Fractionalization, Polarization, and Economic Growth: Identifying the Transmission Channels. In Economic Inquiry, 52 (3), 1204-1218.

Parotta, P., Dario, P., Mariola P. (2010). Does Labour Diversity Affect Firm Productivity? In ASB Working Paper No. $10-12$.

Perotti, R. (1996). Growth, Income Distribution, and Democracy: What the Data Say. In Journal of Economic Growth, 1 (2), 149-187.

Putnam, R. (1995). Bowling Alone: America's Declining Social Capital. In Journal of Democracy, 6 (1), 65-78.

Sokoloff, K., Engerman, S. (2000). History Lessons. Institutions, Factor Endowments, and Paths of Development in the New World. In Journal of Economic Perspectives, 14 (3), 217-232.

Sparber, C. (2010). Racial Diversity and Macroeconomic Productivity across US States and Cities. In Regional Studies, 44 (1), 71-85. 


\title{
Культурная неоднородность
}

\section{и экономическое развитие в России}

\section{A.Н. Буфетова, А.А. Хржановская, Е.А. Коломак}

Институт экономики и организаџии промышленного производства СО РАН

Российская Федерачия, Новосибирск

Новосибирский национальный исследовательский государственный университет

Российская Федерачия, Новосибирск

\begin{abstract}
Аннотация. В статье исследуются изменения в национальной и религиозной структуре населения и оценивается влияние культурной неоднородности на экономическое развитие регионов России. Источниками информации о национальной структуре населения являются переписи 2002 и 2010 годов. Анализ неоднородности религиозной структуры проведен за 2012 и 2015 годы, источником данных являются Атлас религий и национальностей России и Федеральное агентство по делам национальностей. Уровень культурной гетерогенности оценивается с помощью индексов фракционализации и поляризации. Изучение этих характеристик показало, что, несмотря на усиление миграционных процессов в современной России, существенных изменений в культурной неоднородности населения не произошло. В то же время имеет место большое разнообразие национальных и религиозных структур в регионах. Влияние культурной неоднородности на экономическое развитие оценивается с помощью регрессионного анализа. Оценивалась панельная регрессия ВРП на труд, капитал, контролирующие переменные и индексы культурной неоднородности. Результаты показали: 1) положительное влияние этнокультурной фракционализации на экономическое развитие; 2) отсутствие статистически значимой связи между уровнем национальной поляризации и развитием; 3) негативное влияние религиозной поляризации на продуктивность. Полученные результаты свидетельствуют о необходимости учета культурной неоднородности общества в региональной политике и в управлении общественными финансами.
\end{abstract}

Ключевые слова: культурная неоднородность, регионы России, национальность, религия, эмпирический анализ, фракционалиация, поляризация, регрессия.

Статья выполнена при поддержке Российского фонда фундаментальных исследований, проект № 19-310-90010 «Этнокультурное разнообразие, экономическое развитие и проблемы управления в регионах России».

Научная специальность: 08.00.00 - экономические науки. 